\title{
Clinicopathological Evaluation of Cutaneous Leishmaniasis in the Mediterranean Region of Turkey
}

\author{
Akdeniz Bölgesinde Kutanöz Leişmanyazis Olgularının \\ Klinikopatolojik Değerlendirilmesi
}

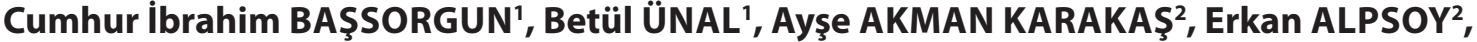 \\ Mehmet Akif ÇifTCioĞLU', Soner UZUN²
}

Department of ${ }^{1}$ Pathology, ${ }^{2}$ Dermatology, Akdeniz University, School of Medicine, ANTALYA, TURKEY

\section{ABSTRACT}

Objective: Cutaneus leishmaniasis, a chronic self-limited disease of the skin, is usually caused by Leishmania Tropica. It is endemic in Southeastern Anatolia. The definitive diagnosis depends on demonstration of the parasites by smear and culture or its identification in tissue section. This study aimed to evaluate clinical and histopathological skin lesions in cutaneous leishmaniasis cases in Antalya, Turkey.

Material and Method: Our study included 28 patients diagnosed with cutaneous leishmaniasis at the Pathology Department of Akdeniz University Medical Faculty. Histopathological sections were stained with Haematoxylin-Eosin, Giemsa or Leishman for visual examination of cellular components by two dermatopathologists. The epidermal (acanthosis, hyper-parakeratosis, atrophy, lymphocytic exocytosis) and dermal changes that may indicate lymphohistiocytic infiltration and granuloma formation were investigated. The parasitic load was classified according to the modified Ridley's parasitic index.

Results: Out of 28 cases, 11 had hyperparakeratosis, 17 had orthokeratosis, 20 had acanthosis, 4 had epidermal atrophy, and 7 had exocytosis. Typical epithelioid cell granulomas with giant cells and a rim of lymphocytes were present in 16 cases. Leishman-Donovan bodies were extremely rare in typical granulomatous lesions. The other 12 cases showed lymphohistiositic infiltration, giant cells and prominent plasma cells. There were numerous Leishman-Donovan bodies in these lesions.

Conclusion: We investigated the epidermal and dermal changes that would facilitate the histopathological diagnosis of cutaneous leishmaniasis in this study. We found that atrophy, acanthosis, and orthokeratosis were early stage indicators, while exocytosis, hyperparakeratosis, and atrophy were indicative of late stage disease.

Key Words: Cutaneous leishmaniasis, Pathology, Granuloma

\section{Öz}

Amaç: Kutanöz leişmanyazis, derinin kronik, kendi kendini sınırlayan bir hastalığıdır. Genellikle etken Leishmania Tropica' dır. Güneydoğu Anadolu'da endemiktir . Kesin tanı yayma ve kültür veya doku kesitlerinde parazitin görülmesi ile sağlanır. Çalışma Akdeniz Bölgesinde saptanan kutanöz leişmanyazise ait deri lezyonların klinik ve histopatolojik olarak değerlendirilmesini içermektedir.

Gereç ve Yöntem: Akdeniz Üniversitesi Tip Fakültesi Patoloji Anabilim Dalı'nda kutanöz leişmanyazisin tanısı alan 28 hasta çalışmaya dahil edildi. Hematoksilin-Eozin, Giemsa veya Leishman ile boyanmış histopatolojik kesitler iki dermatopatolog tarafından incelendi. Lenfohistiyositik infiltrasyon ve granülom oluşumu ile ilişkilendirilebilecek epidermal (akantoz, hiper-parakeratoz, atrofi, lenfositik ekzositoz) ve dermal değişiklikler değerlendirildi. Parazitik yük, modifiye Ridley endeksine göre sinıflandırıldı.

Bulgular: Yirmi sekiz olgunun 17'sinde ortokeratoz, 11'inde hiperparakeratoz , 20 olguda akantoz, 4 olguda epidermal atrofi , 7 olguda ekzositoz saptandı. Onaltı olguda dev hücreler ve lenfositler ile çevrili epiteloid hücrelerden oluşan tipik granülomlar görüldü. Leishman Donovan cisimleri tipik granulomatöz lezyonlarda son derece nadirdi. Diğer 12 olgu lenfohistiyositik infiltrasyon, dev hücreler ve belirgin plazma hücrelerini içermekte idi. Leishman Donovan cisimlerinin bu lezyonlarda sayısı çok fazla idi.

Sonuç: Çalışmamızda, kutanöz leişmanyazisin histopatolojik tanısında yol gösterecek epidermal ve dermal değişiklikleri araştırıp erken evrede atrofi, akantoz, ortokeratoz; geç evrede ekzositoz, hiperparakeratoz, atrofi saptadik.

Anahtar Sözcükler: Kutanöz leişmanyazis, Patoloji, Granülom

Correspondence: Cumhur İbrahim BASSSORGUN

Akdeniz Üniversitesi Tip Fakültesi, Patoloji Anabilim Dalı, ANTALYA, TURKEY

E-mail: drbassorgun@gmail.com Phone: + 902422496384 


\section{INTRODUCTION}

Cutaneous leishmaniasis (CL) is a serious health problem with an increasing worldwide incidence, particularly in tropical regions. The disease is an endemic in the Southeastern Anatolia and Mediterranean regions of Turkey, and mainly concentrated in the Çukurova area (1). In recent years, an increased incidence of CL cases has been observed in Antalya and its environs (2).

$\mathrm{CL}$ is a granulomatous skin disease. This group of diseases usually present with various clinical manifestations, which can pose occasional diagnostic challenges both clinically and histopathologically (3).

The main agent causing $\mathrm{CL}$ is an intracellular parasite called L. tropica. The differential diagnosis of CL requires an accurate identification of the causative parasite. The fastest and easiest method of diagnosis is identifying the causative agent by microscopic examination of Giemsa-stained smears prepared from skin lesions. Identification of the etiological agent from histopathological sections appears to be an important diagnostic tool. Other sensitive modern diagnostic techniques include immunohistochemical and immunofluorescence techniques using monoclonal antibodies, identifying the causative agent through DNA probes, PCR, and electron microscopic studies.

The disease is usually misdiagnosed in non-endemic countries, which leads to significant delays in the treatment of the skin lesions. In general, the disease has complex clinical manifestations such as plaques, papules, nodules or nodulo-ulcerative and lupoid lesions. However, the lesions may become more complicated due to overlapping lesions or secondary infections in patients with delayed diagnosis. These complications might lead to further clinical or histopathological difficulties. Combined with conventional histopathological features, confusing additional findings might interfere with the diagnostic accuracy.

In this study, we examined the histopathological features of the patients diagnosed with $\mathrm{CL}$ and evaluated the relationship with the clinical process.

\section{MATERIAL and METHOD}

Our study included 28 patients diagnosed with CL at the Pathology Department of Akdeniz University Medical Faculty. We identified the intra-and extra-cellular parasites by histopathological examinations in all cases.

The 4-micron-thick histopathological sections were stained with histochemical dyes such as Haematoxylin and Eosin (H\&E), Giemsa or Leishman for visual examination of cellular components by two dermatopathologists. Epidermal changes, acanthosis, hyper-parakeratosis, epidermal atrophy, exocytosis (lymphocytic) and dermal changes were considered to indicate the presence of lymphohistiocytic infiltration and granuloma formation.

The parasitic load was examined at high magnification (40x objective) and classified according to the modified Ridley's parasitic index (4) as +1 for 1-10 parasites, +2 for $10-100$ parasites, and +3 for 100 or above parasites per standard section. A parasitic index of +1 and +2 were defined as "low", and a parasitic index of +3 as "high".

Statistical Analysis: The Kolmogorov-Smirnov test was used to verify the normality of the distribution of continuous variables. Since the duration of disease was not normally distributed, comparison between two groups was made using the Mann-Whitney $U$ test while the chi-square test was used for categorical variables. Analyses were performed with PASW 18 (SPSS/IBM, Chicago, IL, USA) software and two-tailed $\mathrm{P}$ value less than 0.05 was considered statistically significant.

\section{RESULTS}

The mean age of the patients was $19 \pm 8.74$ years. 19 patients were male and 9 were female. The mean clinical duration of disease was $10.5 \pm 6.53$ months. The lesions were localized on the face in 18 patients (64.2\%), upper extremities in 5, lower extremities in 3 and on the back in 2 patients.

We detected papules or nodules in 10 cases, noduloulcerative lesions in 13 cases and lupoid lesions in 5 cases. Of the 28 patients, 11 had hyper-parakeratosis, 17 orthokeratosis, 20 acanthosis, 4 atrophy and 7 exocytosis. Granuloma formation was observed in all of the patients showing exocytosis and hyper-parakeratosis. Orthokeratosis was observed in all cases demonstrating lymphohistiocytic infiltration with no granulomatous features. The Grenz zone was apparent in the cases with lymphohistiocytic cell infiltration.

All 12 patients with lymphohistiocytic cell infiltration showed a parasitic index level of +3 (Figure 1), while 14 patients with granuloma showed a parasitic index level of +1 in 12 cases and +2 in 2 cases (Figure 2).

Of the patients with lymphohistiocytic cell infiltration, 10 had papules or nodules, while 2 patients presented with nodulo-ulcerative lesions. Granuloma formation was observed in all lupoid lesions. Patients demonstrating granuloma formation were chronic cases. In these cases, the median duration of the disease was 12.5 (min.10-max.26) months, and the parasite index level was low. Patients 


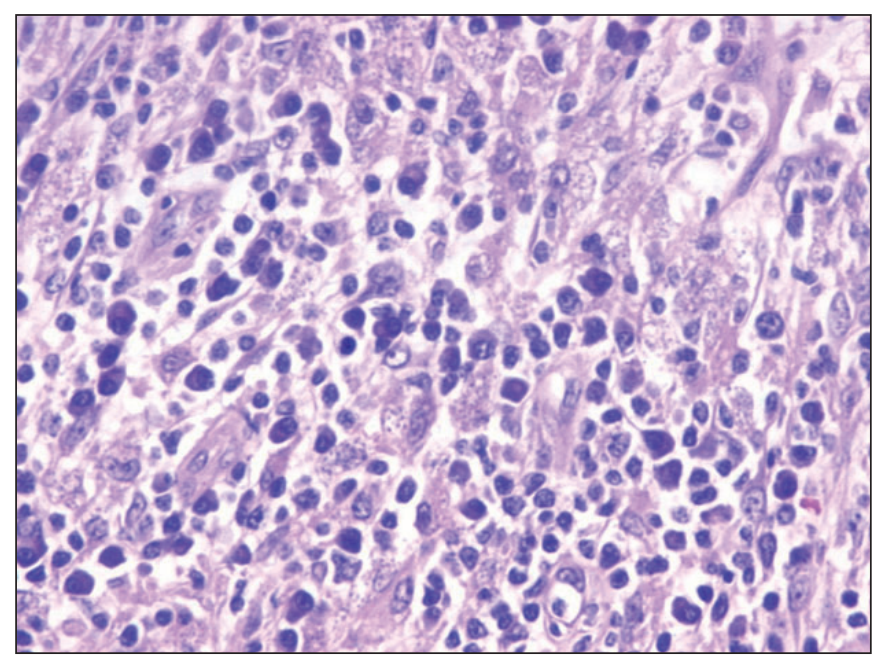

Figure 1: Early lesion of acute cutaneous leishmaniasis showing a mixed inflammatory cell infiltrate. The infiltrate includes parasitized macrophages, plasma cells and lymphocytes. (H\&E; $\mathrm{x} 400)$.

demonstrating lymphohistiocytic cell infiltration were acute cases with a median disease duration of 4 (min.2max.13) months and high index levels (Table I).

The patients with granuloma formation and those with lymphohistiocytic infiltrate were statistically compared. The number of parasites in 12 cases with lymphohistiocytic infiltrate was quite high. The parasite count was lower in the 14 patients with granuloma formation. Due to a relatively small sample size, patients with parasitic index +1 and +2 were defined as "low", and parasitic index +3 was defined as "high". The comparison of the parasite index in cases with lymphohistiocytic infiltrate and granuloma formation showed a $\mathrm{p}$ value of 0.001 after the Chi-square test, which was statistically significant. We found that the number of parasites was significantly high in acute cases with lymphohistiocytic infiltrate, whereas chronic cases presenting granuloma formation had a relatively lower parasite count. These findings were statistically significant (Table II).

Cases with lymphohistiocytic infiltration had a significantly lower median disease duration than those with granuloma formation. The Mann-Whitney $U$ test showed a $p$ value of 0.001 in the comparison of duration of disease with lymphohistiocytic infiltrate and those with granuloma formation. Another comparison that evaluated those with a median disease duration of less than 12 months and over 12 months revealed statistically significant results. 15 cases with a disease duration of less than 12 months were acute and 13 cases with over 12 months were chronic. The comparison of median disease duration in cases with

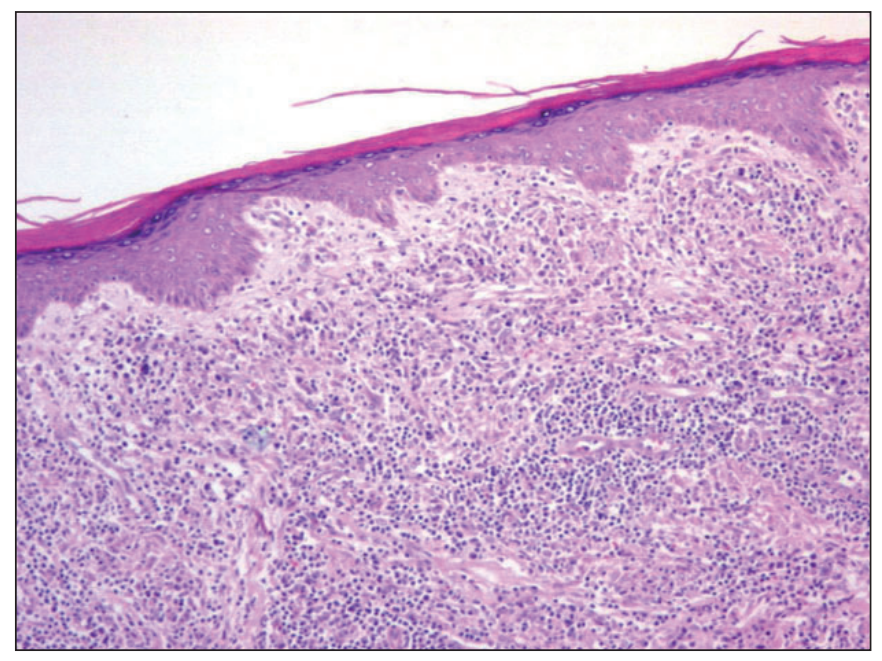

Figure 2: Late lesion of acute cutaneous leishmaniasis showing an infiltrate predominantly composed of parasitized macrophages with a variable number of lymphocytes, hyperparakeratosis and acanthosis (H\&E; x100).

lymphohistiocytic infiltrate and granuloma formation showed a $\mathrm{p}$ value of 0.001 after the Chi-square test, which was statistically significant.

\section{DISCUSSION}

Over the recent years, cutaneus leishmaniasis (CL) has attracted more attention due to its increasing incidence in subendemic regions. Cases of CL are also seen in nonendemic areas, mainly in people with a history of recent travel to endemic regions. The disease usually presents with painless skin lesions in the external parts of the body. In addition, superinfections or incorrect treatment procedures may complicate the clinical picture and create difficulty in diagnosis, which may delay the treatment. Atypical presentations of the disease can also compromise the accuracy of the diagnosis and treatment.

Lever has classified the early and late stage lesions based on their duration as "acute leishmaniasis", characterized by the presence of lesions lasting 1-2 years from emergence, and "chronic leishmaniasis", characterized by the presence of lesions lasting more than 2 years (5). In the early stages, clinical findings include papules, nodules, plaques and nodulo-ulcerative lesions, while in the late stages, lupoid lesions are observed. For patients in subendemic areas such as Antalya, substantial overlap lesions occur especially in the late stages if the disease is not included in the diagnostic considerations, which makes the pre-diagnosis challenging. In this case, the histopathological findings might be misinterpreted by the pathologist as other granulomatous lesions, inflammation, ulceration, or even lymphoma. To 
Table I: Distribution of patients by age, sex, lesion type, lesion site, histopathological features, parasitic index and duration

\begin{tabular}{|c|c|c|c|c|c|c|c|c|c|}
\hline Case & Age & Lesion type & Site & Str.Corneum & Epi & ermis & Dermis & $\begin{array}{c}\text { Parasitic } \\
\text { index }\end{array}$ & $\begin{array}{c}\text { Duration } \\
\text { Time(month) }\end{array}$ \\
\hline 1 & 30 & Lupoid & Chin & HPP & $\mathrm{AC}$ & $\mathrm{EXO}$ & GR & 1 & 24 \\
\hline 2 & 28 & Lupoid & Forearm & HPP & $\mathrm{AC}$ & EXO & GR & 1 & 20 \\
\hline 3 & 13 & Lupoid & Back & HPP & $\mathrm{AC}$ & & GR & 1 & 19 \\
\hline 4 & 21 & Lupoid & Leg & $\mathrm{HPP}$ & $\mathrm{AC}$ & $\mathrm{EXO}$ & GR & 1 & 15 \\
\hline 5 & 14 & Lupoid & Cheek-Chin & HPP & $\mathrm{AC}$ & & GR & 1 & 26 \\
\hline 6 & 15 & Nodulo-ulcerative & Cheek & $\mathrm{HPP}$ & $\mathrm{AC}$ & & GR & 1 & 10 \\
\hline 7 & 12 & Nodulo-ulcerative & Elbow & HPP & $\mathrm{AC}$ & EXO & GR & 1 & 10 \\
\hline 8 & 10 & Nodulo-ulcerative & Elbow & HPP & $\mathrm{AC}$ & & GR & 1 & 11 \\
\hline 9 & 30 & Nodulo-ulcerative & Forehead & HPP & $\mathrm{AC}$ & & GR & 1 & 12 \\
\hline 10 & 25 & Nodulo-ulcerative & Cheek & HPP & $\mathrm{AC}$ & $\mathrm{EXO}$ & GR & 1 & 12 \\
\hline 11 & 13 & Nodulo-ulcerative & Chin & HPP & $\mathrm{AC}$ & $\mathrm{EXO}$ & GR & 2 & 13 \\
\hline 12 & 15 & Nodulo-ulcerative & Forearm & $\mathrm{OK}$ & $\mathrm{AC}$ & EXO & GR & 1 & 11 \\
\hline 13 & 30 & Nodulo-ulcerative & Cheek & $\mathrm{OK}$ & $\mathrm{AC}$ & & GR & 2 & 13 \\
\hline 14 & 14 & Nodulo-ulcerative & Preauricular & $\mathrm{OK}$ & $\mathrm{AC}$ & & GR & 1 & 12 \\
\hline 15 & 26 & Nodulo-ulcerative & Left Zygoma & $\mathrm{OK}$ & $\mathrm{AC}$ & & GR & 1 & 12 \\
\hline 16 & 9 & Nodulo-ulcerative & Nose & $\mathrm{OK}$ & $\mathrm{AC}$ & & GR & 3 & 16 \\
\hline 17 & 14 & Papule & Nose & $\mathrm{OK}$ & $\mathrm{AC}$ & & LHI & 3 & 5 \\
\hline 18 & 10 & Nodule & Left Cheek & $\mathrm{OK}$ & $\mathrm{AC}$ & & LHI & 3 & 13 \\
\hline 19 & 13 & Nodule & Chin & $\mathrm{OK}$ & $\mathrm{AC}$ & & LHI & 3 & 2 \\
\hline 20 & 17 & Nodule & Cheek & $\mathrm{OK}$ & $\mathrm{AC}$ & & LHI & 3 & 7 \\
\hline 21 & 10 & Nodule & Right Back & $\mathrm{OK}$ & $\mathrm{AT}$ & & LHI & 3 & 7 \\
\hline 22 & 8 & Papule & Leg & $\mathrm{OK}$ & AT & & LHI & 3 & 6 \\
\hline 23 & 45 & Nodule & Leg & $\mathrm{OK}$ & AT & & LHI & 3 & 4 \\
\hline 24 & 15 & Nodule & Forearm & $\mathrm{OK}$ & $\mathrm{AT}$ & & LHI & 3 & 4 \\
\hline 25 & 28 & Nodule & Cheek & $\mathrm{OK}$ & & & LHI & 3 & 2 \\
\hline 26 & 19 & Papule & Cheek & $\mathrm{OK}$ & & & LHI & 3 & 3 \\
\hline 27 & 29 & Nodule & Temporal & $\mathrm{OK}$ & & & LHI & 3 & 3 \\
\hline 28 & 19 & Papule & Temporal & $\mathrm{OK}$ & & & LHI & 3 & 2 \\
\hline
\end{tabular}

HPP: Hyperparakeratosis, OK: Orthokeratosis, AC: Acanthosis, AT: Atrophy, EXO: Exocytosis, LHI: Lymphohistiocytic infiltration, GR: Granuloma.

Table II: The distribution of patients according to parasitic index, granuloma formation and lymphohistiocytic infiltrate

\begin{tabular}{|l|c|c|c|}
\hline \multicolumn{1}{|c|}{ Distribution of patients } & $\begin{array}{c}\text { Parasitic index } \\
\text { low }(+\mathbf{1},+\mathbf{2})\end{array}$ & $\begin{array}{c}\text { Parasitic index } \\
\text { high }(+\mathbf{3})\end{array}$ & Total number of patients \\
\hline Granuloma formation & 14 & 2 & 16 \\
\hline Lymphohistiocytic infiltration & 0 & 12 & 12 \\
\hline Total number of patients & 14 & 14 & 28 \\
\hline
\end{tabular}

reduce such problems, CL should always be included in the differential diagnosis during the clinical and pathological evaluation of the cases.
Recognition of the parasite in the examination of a touch preparation from cutaneous lesions is one of the most challenging aspects in the diagnosis. Histochemical 
staining of the cells with Giemsa or Giemsa modified Leishman's stain exposes the intracellular and extracellular parasites. In histopathological sections, the parasites may be confused with tingible body, fungal elements, toxoplasma, histoplasmosis or artifacts. At times, especially in the granulomatous lesions of chronic leishmaniasis, identifying the parasite can be difficult. In this case, a microscopic examination using numerous serial crosssections will be a correct choice. In our study, we detected several Leishmania particles in granuloma structures after analyzing numerous series of cross-sections. In cases where $\mathrm{H} \& \mathrm{E}$ or Giemsa staining fails to identify any Leishmania particles, other sensitive diagnostic techniques, including immunohistochemical and immunofluorescence techniques as well as molecular methods such as DNA probes or PCR, can be used to identify the causative agent.

In the early stages of CL, a histopathological examination might reveal plasma cells or giant cells along with lymphohistiocytic cell infiltration. At this stage, the parasite load is quite heavy in patients. In the later stages of the disease, the number of parasites gradually decreases in proportion to the disease duration, and distinct granuloma structures are observed. Consistent with the results of the previous research, our study detected similar characteristic histopathological features $(6,7)$.

In the histopathological diagnosis of CL, epidermal changes may have a significant diagnostic value. While Mahregan et al. reports that patients in the early stages of the disease may demonstrate hyper-parakeratosis, atrophy, acanthosis, exocytosis, pseudoepitheliomatous hyperplasia, and basal vacuolar degeneration (5), we only observed atrophy, acanthosis and orthokeratosis in our cases at early stages. In the late stages, we detected exocytosis, hyper-parakeratosis and atrophic lesions. Although these findings are not statistically significant due to the limited sample size, we consider that further studies with larger sample sizes can provide new data other than the current histopathological features, which will contribute to the diagnosis of CL.

Definitive diagnosis of CL can only be made by histopathological identification of the parasite. In cases with lymphohistiocytic infiltration and granulomatous inflammation where the causative parasite cannot be identified, CL should be included in the diagnostic considerations. As in all types of skin diseases, clinicopathological correlation is also required in the diagnosis of CL.

\section{REFERENCES}

1. Uzun S, Uslular C, Yucel A, Acar MA, Ozpoyraz M, Memisoglu HR. Cutaneous leishmaniasis: Evaluation of 3074 cases in the Cukurova Region of Turkey. Br J Dermatol. 1999;140:347-50.

2. Akman A, Durusoy C, Seckin D, Alpsoy E. Antalya' da görülen Kutanoz Layşmanyazis olgularının epidemiyolojik özellikleri. Turkderm. 2007;41:93-6.

3. Memisoglu HR. Kutanöz leishmaniasis. Aknem Derg. 1997;11:319-29.

4. Ridley DS, Ridley MJ. The evaluation of the lesion in cutaneous leishmaniasis. J Pathol. 1983;141:83-96.

5. Lever WF. Histopathology of the skin. 9th ed. Philadelphia: JB Lippincott Company; 2004.

6. Venkataram M, Moosa M, Devi L. Histopathological spectrum in cutaneous leishmaniasis: A study in Oman. Indian J Dermatol Venereol Leprol. 2001;67:294-8.

7. Ridley DS. A histological classification of cutaneous leishmaniasis and its geographical expression. Trans R Soc Trop Med Hyg. 1980;74:515-21. 